\title{
Opportunities and challeges of tourist valorization of Zambratija cove (Umag)
}

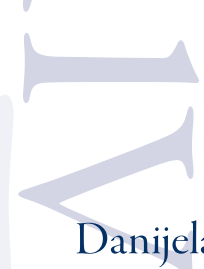

\author{
Ida Koncani Uhač, Archaeological Museum of Istria
}

Neven Iveša, Juraj Dobrila University of Pula

Danijela Mioković, Croatian Agricultural and Forestry Advisory Service

Ana Žužić, Fisheries Local Action Group „Pinna nobilis“

Območje okrog Zambratijskega zaliva je zaradi arheoloških zakladov edinstvena destinacija za raziskovalce. Leta 2008 so bile odkrite nove arheološke najdbe, ki veljajo za prvovrstna arheološka odkritja. Ključne besede: Zambratijski zaliv, območje posebnega upravljanja, arheološka odkritja, prazgodovinska poselitev, Prehistoric sewn boat, trajnostna raba, biološka študija, pilotni projekt

The area surrounding Zambratija Cove has been representing a unique destination for researchers due to its archaeological treasures. In 2008 new archaeological findings were discovered, which, as a result of its uniqueness, can be classified at the very top of archaeological discoveries.

Keywords: Zambratija Cove, Special management zone, Archaeological discoveries, Prehistoric settlement, Prehistoric sewn boat, Sustainable use, Biological study, Pilot project, Citizen survey

\section{Introduction}

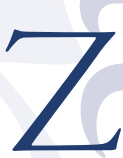

ambratija Cove is situated on the mild, low-lying north-western coast of the Istrian peninsula. The cove is surrounded by the Sipar peninsula in the south and Crvena uvala in the north.

The rich cultural and historical heritage of this region has always attracted the attention of many researchers. Along with several archaeological sites, known in the wider area around Zambratija, in 2008 new archaeological findings in the northern part of Zambratija Cove were discovered, ' which, as a result of its uniqueness, can be classified at the very top of archaeological discoveries. Zambratija Cove has become a place of intense archaeological research since 2008, especially after the discovery of prehistoric sites. ${ }^{2}$ The archaeological discoveries from the underwater world and those found on land are

Koncani Uhač, "Podvodna arheološka istraživanja," 263-68.

Koncani Uhač, "Zambratija-uvala," 396-97. evidence of the rich history of the area, which has been inhabited since the early Copper Age, through the Roman period and the Middle Ages to the present.

\section{The hidden treasure of Zambratija cove}

One of the most significant sites is that of the remnants of a prehistoric settlement dated to the period from the late Neolithic to the early Eneolithic (fifth to fourth millennia BCE). Preserved on the seabed are the remnants of prehistoric pile dwellings that were likely built in a marshland valley near the open sea. The archaeological data collected in the course of excavation work at the site indicate that the prehistoric inhabitants of Zambratija lived in a community and that they were farmers, hunters and fishers. The plant and animal remains bear witness to their diverse diet and are indicative of cattle breeding. Potsherds from a variety of vessels were collected from the site of the prehistoric settlement along with flint and bone tools. Some of the forms of 
ware are from the Nakovana culture group and are characterised by fluted decoration from the early Copper Age, while other recovered potsherds are from ware covering a broad range of dates from the early Copper Age to the dawn of the Bronze Age. ${ }^{3}$ Finds of Bronze Age ware recovered from the cove can be associated with the nearby Romanija hillfort.

Of interest are the results of the botanical analysis of the plants from the archaeological layers of the settlement, which indicate the presence of water plants in the archaeological layer that are characteristic of natural wet habitats, i.e. wet meadows. The geoarchaeological research conducted at the site last year will soon yield a clearer picture of the palaeo-landscape of this settlement. Some one thousand pile dwellings have been identified in the Alps, situated for the most part on the shores of lakes, in wetland areas or on rivers. The specificity of Zambratija in the group of sites of this kind is its present marine location; with this submerged settlement constituting a significant contribution to the study of Holocene sea levels. In Slovenia we find analogies to the Zambratija site pile dwellings at the sites of settlements in the Ljubljana Marshes (site Ljubljansko barje).

The second prehistoric site in Zambratija Cove is that of the find of a sewn boat. ${ }^{4}$ The discovery in 2008 was followed by archaeological excavation at the site of the sewn boat find that ran through to 2013. This was followed by post-site and laboratory research. The age of the Zambratija boat, determined using radiocarbon methods, dates its construction to the period from the thirteenth to tenth century BCE, i.e. at the transition from the Bronze to the Iron Age. Laboratory analysis of wood samples from the boat structure indicates the use of the wood of five different tree species. The boat builders used different kinds of wood in the construction, with the planks made of elm (Ulmus sp.), the ribs of alder (Alnus Mill.), the laths above

\footnotetext{
3 Koncani Uhač and Čuka, "Doprinos," 34-44.

4 Koncani Uhač and Uhač, "Prapovijesni brod iz uvale Zambratija," $533-38$.
}

the joints of the planks made of fir (Abies alba Mill.), and the treenails of poplar (Populus sp.). ${ }^{5}$ An analysis of the boat's architecture established that the Zambratija vessel is the oldest find of a sewn-built boat in the Mediterranean sphere. ${ }^{6}$ Due to its design characteristics, build type and early date the Zambratija boat is considered an archetype in the sewn boat tradition of the Adriatic sphere. ${ }^{7}$ Its discovery provides a point of reference in the study of the origin and evolution of plank built boats in the Mediterranean and provides the first archaeological evidence of the role of the monoxylon in the development of plank built boats in the northern Mediterranean, and in particular in the northeast of the Adriatic Sea. ${ }^{8}$

An exhibition featuring "Zambratija: Prehistoric Sewn Boat" opened in Pula in 2017, followed by showings in 2018 in Zagreb, Sibenik and other venues. This traveling exhibition has as its objective to raise awareness in the specialist and broader public, and in particular among youth, of the find of this boat, the oldest Mediterranean specimen of its kind, in the waters of the Adriatic Sea. An effort has also been made to offer the broader public a tactile appreciation of the boat, to which end a reconstruction has been undertaken of a two by one metre section of the boat. The fabrication of the section of the boat through experimental archaeology has yielded data on the method of its construction, with work on the reconstruction shown as a video to visitors of the exhibition. Joining the archaeologists in the fabrication of the boat section were members of the "Savudrijska batana - Batana salvorina" association. The work of this association includes the fabrication of the batana boats specific to the micro-region. It all comes together in a story that has some similarity in terms of shipbuilding with the Zambratija sewn boat. Also preserved from the rich period of Roman

\footnotetext{
Ferreira Dominguez, Boetto, Guibal and Cenzon-Salvayre, "Wood analysis," 60-64.

Koncani Uhač and Uhač, "La barca protostorica," 29-33.

Koncani Uhač, Uhač and Boetto, "Il relitto," 214-19.

Koncani Uhač, Boetto and Uhač, "Zambratija: Prapovijesni šivani brod;" Boetto, Koncani Uhač and Uhač, "Sewn ships," 189-92.
} 
rule in Istria in the waters off Zambratija are the remnants of a former Roman road and structures that were built along the present day shallows at Plič and Zanestra. The road was built on a natural limestone ridge running in the direction of the shoreline towards the west end of the cove. A very well preserved seventy-two-metre section of the road is the first known find of its kind in the waters surrounding Istria. It is hypothesised that the cited shallows were once part of a single shoreline along which the now submerged road ran, with a maritime villa site at the small harbour at Zambratija to the southeast side of the cove.

\section{"Special management zone in Zambratija cove (Umag)" pilot project}

The local population, members of the "Savudrijska batana - Batana salvorina" Sea and Cultural Attractions Association, have recognized the cultural, historical and biological importance of the cove and the possibility of developing new tourist, cultural and educational products. At the initiative of the "Batana Salvorina" Association, and with technical support from "Pinna nobilis" Fisheries Local Action Group (FLAG), a pilot project entitled "Special Management zone in Zambratija Cove (Umag)" was developed. The pilot project was implemented from January to July of 2017 under Measure III.I. "Preparatory Aid", and it was co-founded by the European Maritime and Fisheries Fund.

The aim of the pilot project was to encourage discussion among all interested citizens, in particular among representatives of the fisheries sector, on the opportunities and challenges of establishing a special management zone in Zambratija Cove due to its historical and potential tourist value. Within the framework of the pilot project activities, a survey was conducted involving the citizens of Umag and its surroundings. The project also included the organization of two workshops for representatives of the fisheries, tourism, culture and other sectors, as well as for interested members of the public. After the workshops, there was a consultation meet- ing with representatives of the three sectors, followed by the mapping and development of a biological study of Zambratija Cove and the public presentation of the pilot project's results.

A citizen survey was conducted in order to examine how familiar citizens are with the archaeological findings, as well as to determine their opinion on initiating an evaluation of the aforementioned underwater cultural heritage. At the first workshop, participants were given information about project activities, and their attention was focused on the evaluation of the Zambratija Cove archaeological sites. At the second workshop, participants were introduced to examples of best practice from special management zones in Italy and Croatia.

Also, some practical work was included through group work on the topic of designing the long-term use of Zambratija Cove for fishing, educational and tourism purposes. In addition to the workshops, a consultation was held with representatives of these three sectors from Umag, with the aim of gathering additional proposals and initiatives for the evaluation of the cove, which were sent for further consideration in order to design the final development process of the cove. The mapping and biological study of the submarine area of Zambratija Cove was developed with the aim of proposing guidelines for future sustainable use and management, with an emphasis on strengthening educational, cultural and tourist capacities and further involving local stakeholders in implementing development scenarios for the cove. The final, important pilot project activity was the public presentation of the results.

\section{Study of underwater communities in the Zambratija cove}

The Biological Study of the Zambratija Cove was created for the purpose of the pilot project called "Special Management Zone in the Zambratija Cove" to determine the existing state of natural resources and to set recommendations for use, valorisation and management of the site, including underwater archaeological heritage sites. 
For the purposes of this study, field research was conducted in Zambratija Cove during May, June and early July of 2017. The habitat and biocenoses were determined and the inventory of the associated flora and fauna was made.

It has been established that the following strictly protected species are present in the Zambratija Cove: the bivalves Lithophaga lithophaga (Linnaeus, 1758), Pinna nobilis (Linnaeus, 1758) and Pholas dactylus (Linnaeus, 1758), the sponge Geodia cydonium (Linnaeus, 1767), the seagrass Cymodocea nodosa (Ascherson, 1870) and algae Cystoseira amantacea (Bory de Saint-Vincent, I832). Given the importance of these species in the trophic chain, these findings are proving the biological value of Zambratija Cove. The high abundance of bivalve Pinna nobilis is especially significant.

Underwater survey in Zambratija Cove has determined presence of 244 species, of which 2 species of cyanobacteria, 3 plant species, 30 species of algae, 158 species of invertebrates, 7 species of tunicates and 44 fish species. The phylum Mollusca was represented with the highest number of taxa (56), while only one species from phyla Platyhelminthes and Sipuncula were found. Fish were represented with is families and family Sparidae included the most species (II). The least represented were families Carangidae, Moronidae, Mullidae, Pomacentridae, Torpedininae, Trachinidae and Triglidae, with only one species.

The effects of negative anthropogenic influences, such as degraded marine habitats, especially the mediolitoral and infralitoral, have also been reported. Different waste was commonly found in the infralitoral zone; packaging plastics, glass and metal, rubber, fishing material (rope, nets and signalling equipment) and bulky waste. In the shallow part of the cove and on the rocky ridge, the infralitoral rocks have been degraded by the illegal collection of date shells (Lithophaga lithophaga). The settlements of infralitoral algae near the anthropogenised sea shore have been degraded to a lesser extent, while the entire area of strictly protected seaweed Cymodocea nodosa is almost completely ruined, partly due to fishing for bivalve molluscs that live in the sand. Infralitoral biocenoses are also affected by presence of the sewage outlet that lets wastewater overflow in the conditions of large quantities of rainfall. ${ }^{\text {? }}$

\section{Citizen survey results}

One of the activities of the "Special Management Zone in Zambratija Cove (Umag)" pilot project was a citizen survey, which was conducted in order to investigate citizens' knowledge of the archaeological findings, as well as to determine their opinion on initiating the evaluation of the underwater cultural heritage discovered so far.

The survey was conducted using a survey questionnaire from February to April of 2017 , covering a total of Ior respondents. All respondents were familiar with the subject of the survey, as the purpose of the questionnaire was briefly described on the opening page. Data processing was performed automatically using the SELECT package within the SurveyMonkey online platform, www.surveymonkey.com. The SELECT package allows the creation of survey questionnaires, the collection of respondents' opinions online, the manual entry of responses, and the separate storage of each respondent's questionnaire. The online platform recorded the responses digitally, in percentages and average values, and presented them graphically, thus minimizing the possibility of researcher error.

\section{Overview of selected suvey results}

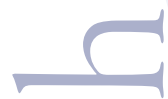

The data in charts I to 4 show the structure of respondents, with variables showing the respondents place of residence, age, gender and field of employment.

It is apparent that more than $44 \%$ of the respondents live in the city of Umag, followed by respondents living in Zambratija (13.9\%), Lovrečica (I0.9\%) and Bašanija (6.9\%). Most respondents belong to the age group from 26 to $40(40.6 \%)$ and from 4 I to $55(23.8 \%)$. A total of

9 Iveša, Morska staništa u uvali Zambratija. 


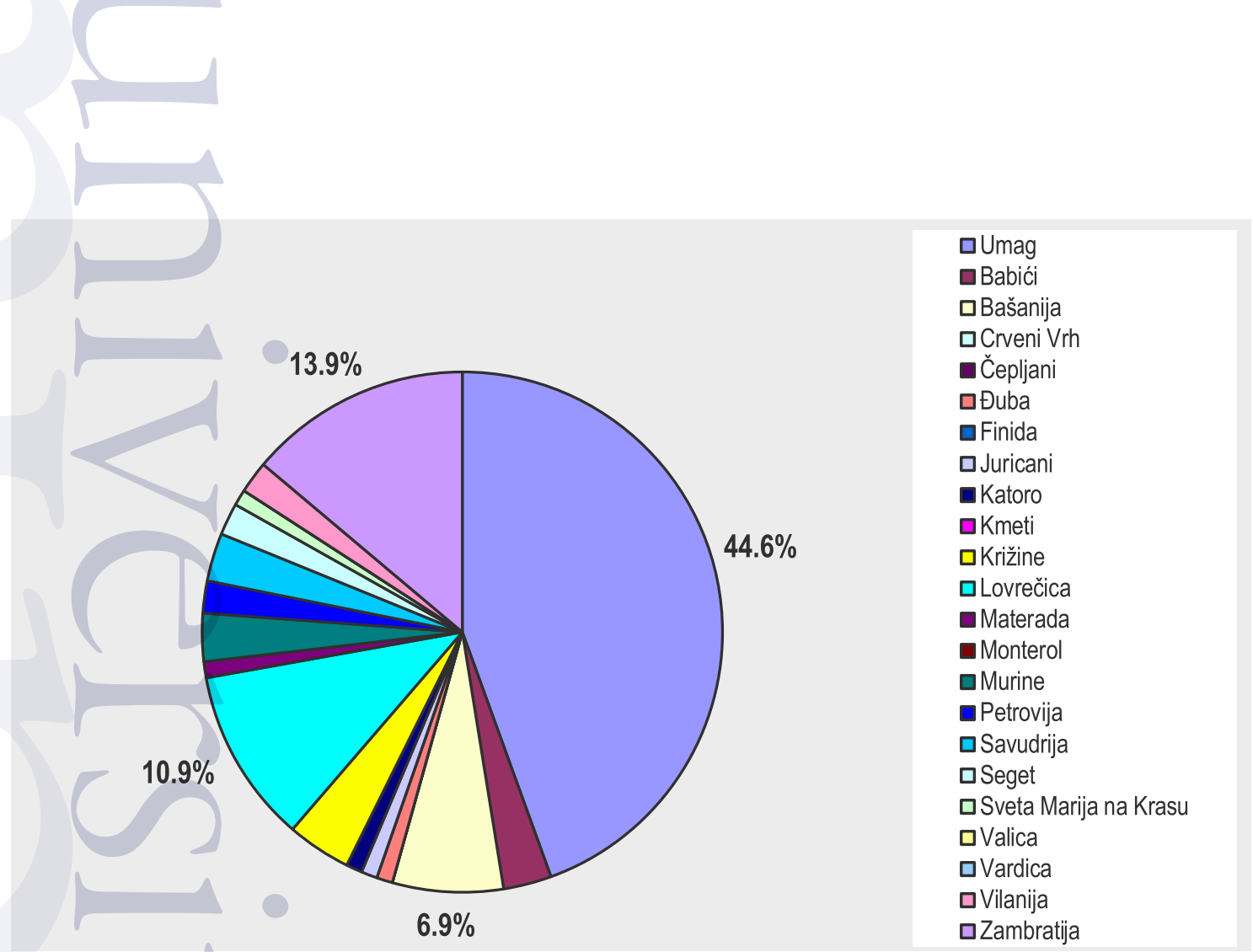

Chart I: Respondents' place of residence (Source: "Pinna nobilis" FLAG through SurveyMonkey online survey platform, www.surveymonkey.com)

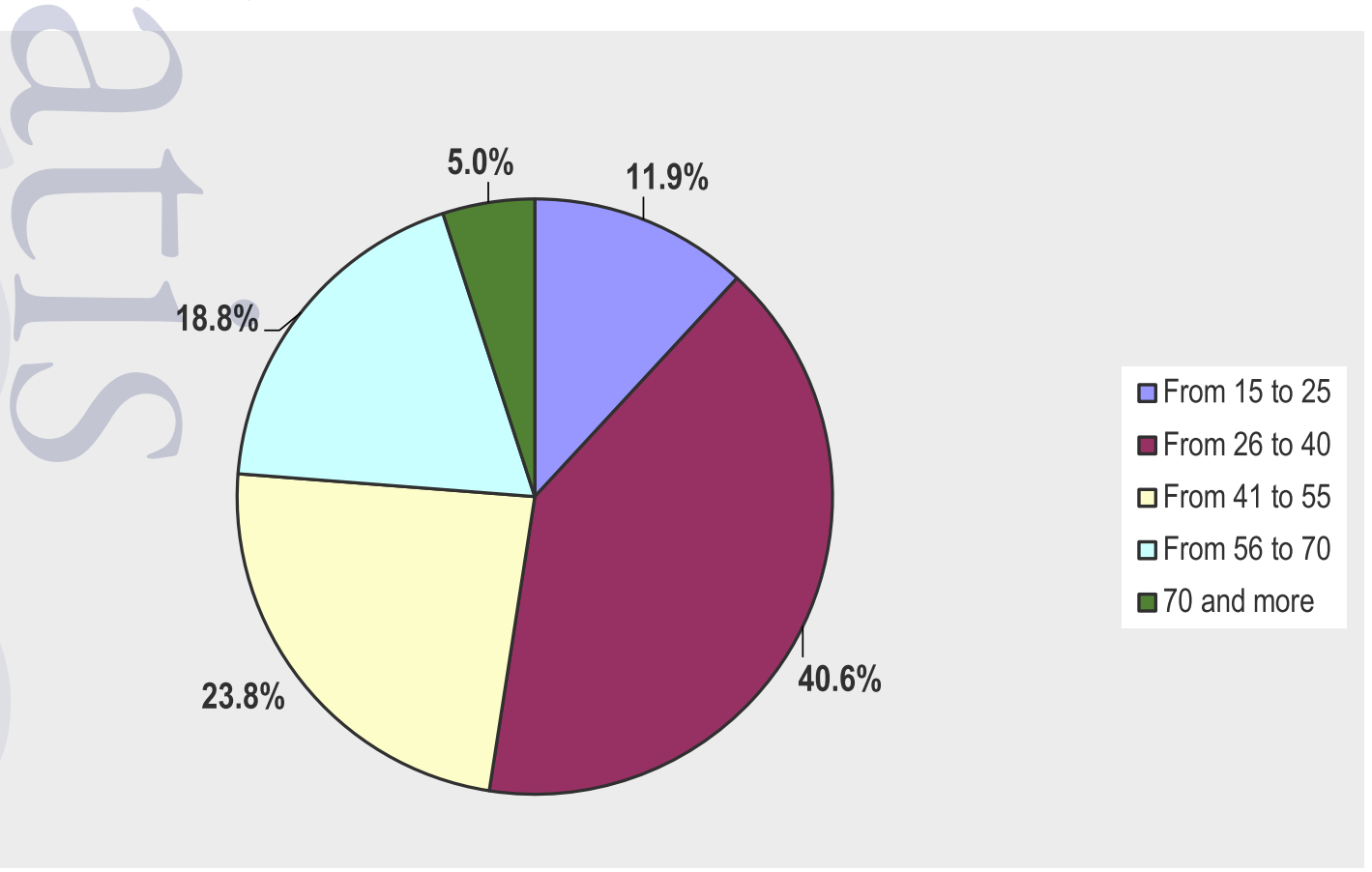

Chart 2: Age structure of respondents (Source: "Pinna nobilis" FLAG through SurveyMonkey online survey platform, www.surveymonkey.com) 


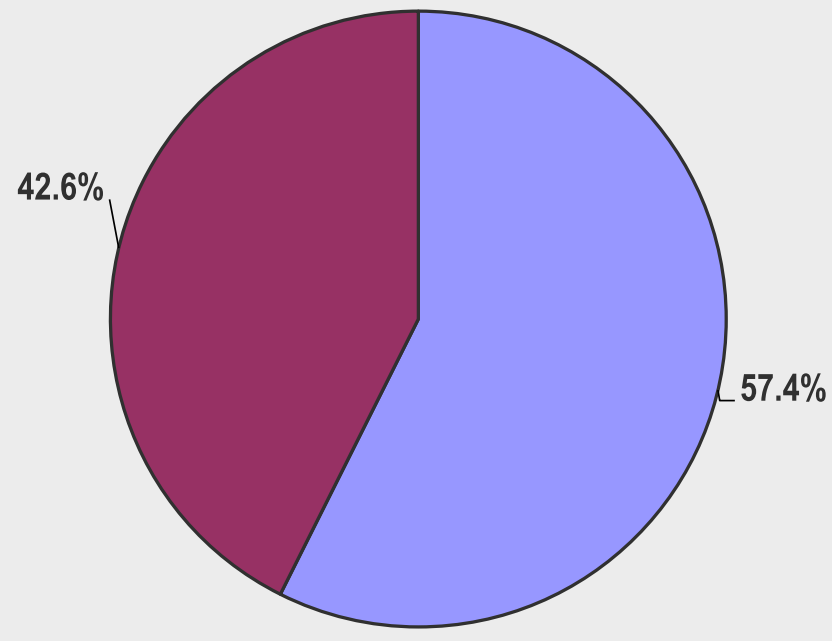

口Male

$\square$ Female

Chart 3: Gender structure of respondents (Source: "Pinna nobilis" FLAG through SurveyMonkey online survey platform, www.surveymonkey.com)

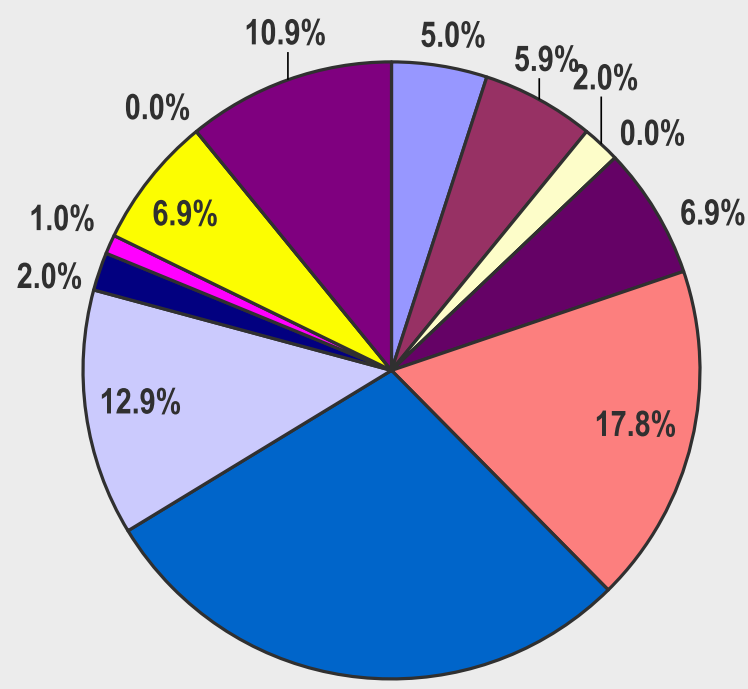

$28.7 \%$
口Pupil

口Student

口State administration

口Regional administration

- City/municipality

口Fisheries sector

-Tourism sector

口Other economic sectors

- Non-governmental, civil sector (civil society association)

口Health care

\section{口Education}

口Social care

Chart 4: Respondents' field of employment (Source: “Pinna nobilis" FLAG through SurveyMonkey online survey platform, www.surveymonkey.com) 


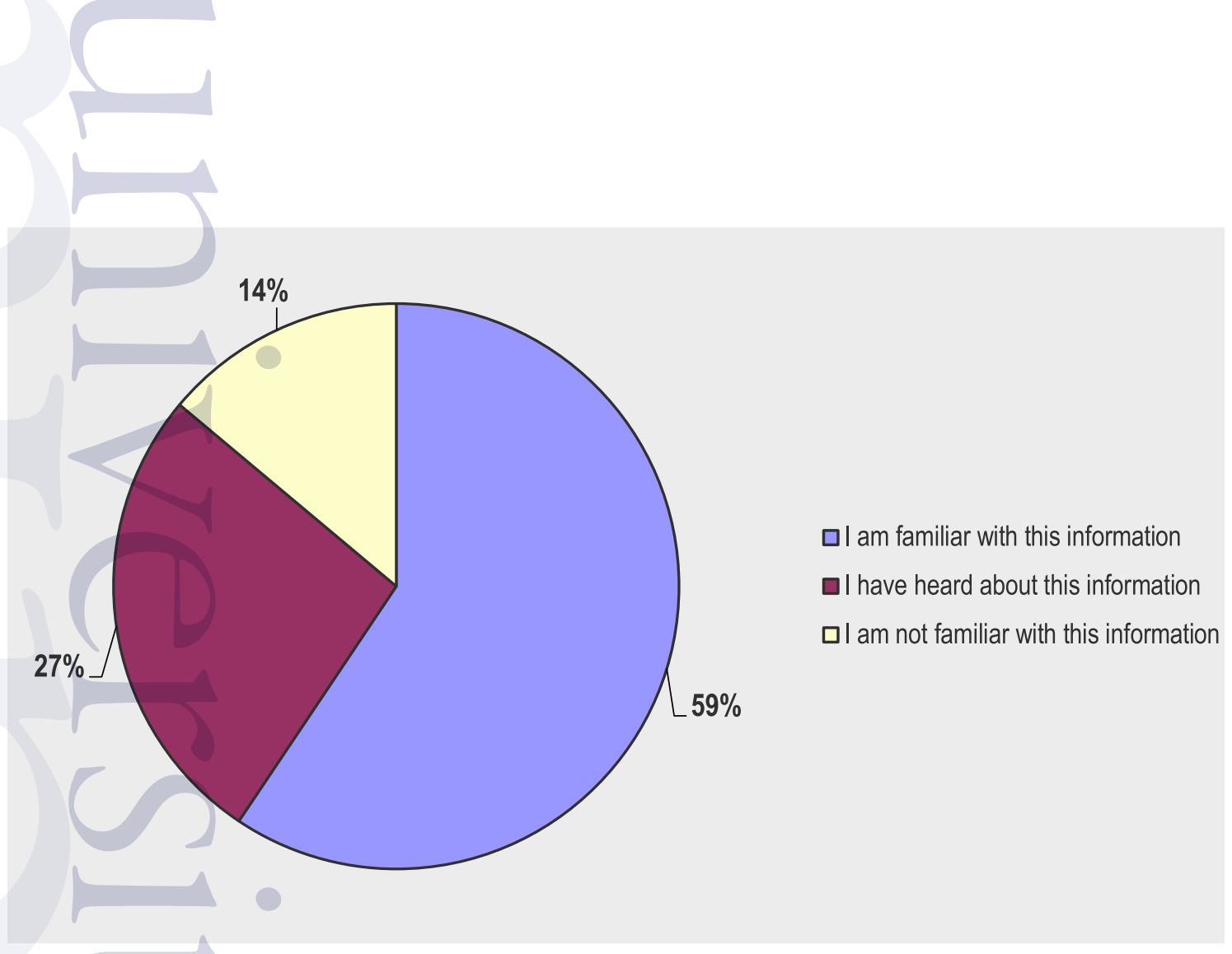

Chart s: Citizens' knowledge of the underwater cultural heritage in Zambratija Cove (Source: "Pinna nobilis" FLAG through SurveyMonkey online survey platform, www.surveymonkey.com)

$57.7 \%$ men and $42.6 \%$ women participated in the survey. The survey included $28.7 \%$ of respondents who work in the tourism sector, $17.8 \%$ from the fisheries sector, $12.9 \%$ from other economic sectors, and $6.9 \%$ from the city / municipal government and education sector.

At the very beginning of the survey, it was important to determine whether the respondents were aware of the fact that there was a flooded prehistoric settlement and an ancient ship in Zambratija Cove, especially since informing citizens of their own cultural heritage is part of the sustainable use of the cove. Chart 5 shows that $40.6 \%$ of citizens are not fully informed about this data, while $59.4 \%$ of respondents are informed. In addition, $57.4 \%$ of respondents believe that the underwater cultural heritage in Zambratija Cove has been insufficiently researched, $22.8 \%$ think it has been partially researched, and $19.8 \%$ think it has been sufficiently researched (Chart 6).

Chart 7 shows that more than $90 \%$ of respondents believe that the local communi- ty, as well as the local tourism sector (which is the main source of income in the surveyed area) should develop specifically towards the sustainable use of both cultural and natural resources.

The results from charts 5, 6 and 7 indicate the need for greater information, education and strengthening of public awareness about the value of archaeological heritage as a bearer of identity, a sense of belonging, recognition and the potential for sustainable use. They also point to the need to involve the public in the design of potential initiatives that will contribute to the sustainable use of cultural and natural wealth. The notion of sustainability is quite common in public discourse today, and it is to be expected that citizens believe their community should develop in accordance with the principles of sustainability.

It is, however, necessary to provide citizens with information on their own cultural and historical heritage and to encourage their participation in the creation and implementation of programmes to consolidate knowledge while simultaneously offering innovative content fo- 


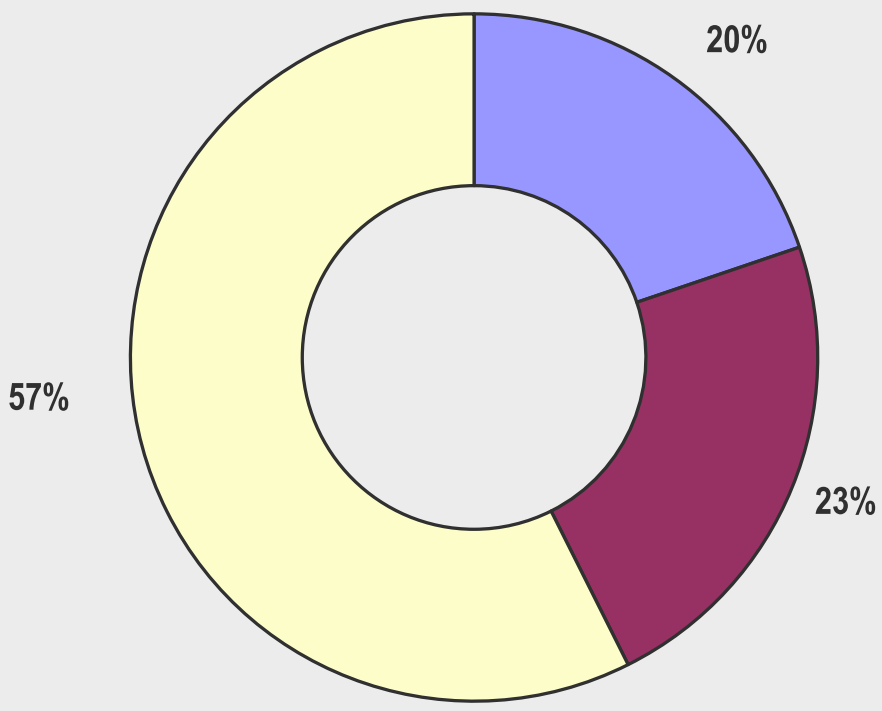

口Sufficiently validated

-Partially validated

口Insufficiently validated

$23 \%$

Chart 6: Citizens' opinion of the current level of research of underwater cultural heritage in Zambratija Cove (Source: "Pinna nobilis" FLAG through SurveyMonkey online survey platform, www.surveymonkey.com)
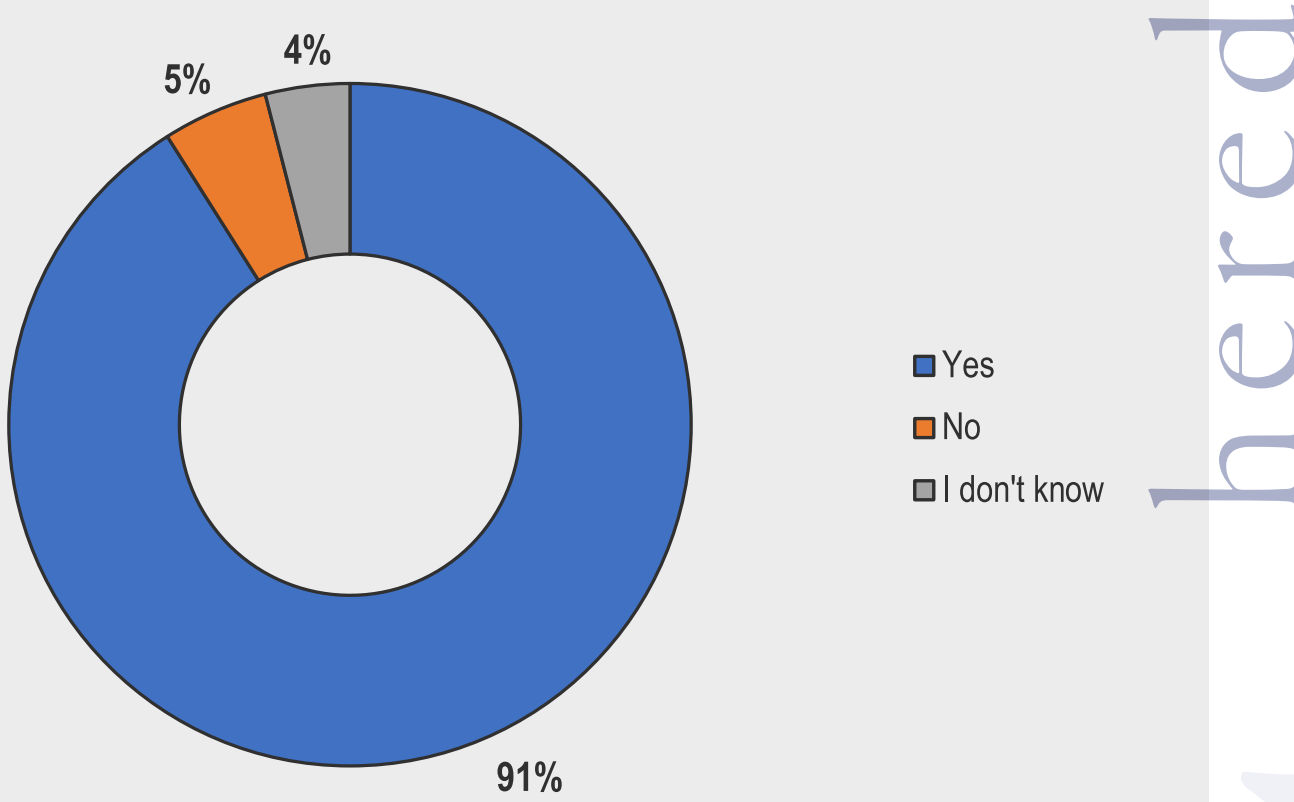

$\square$ Yes

$\square$ No

口। don't know

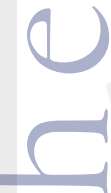

Chart 7: Respondents' opinions on whether the local community and local tourism sector should be developed in accordance with the sustainable use of cultural and natural goods (Source: "Pinna nobilis" FLAG through SurveyMonkey online survey platform, www.surveymonkey.com) 


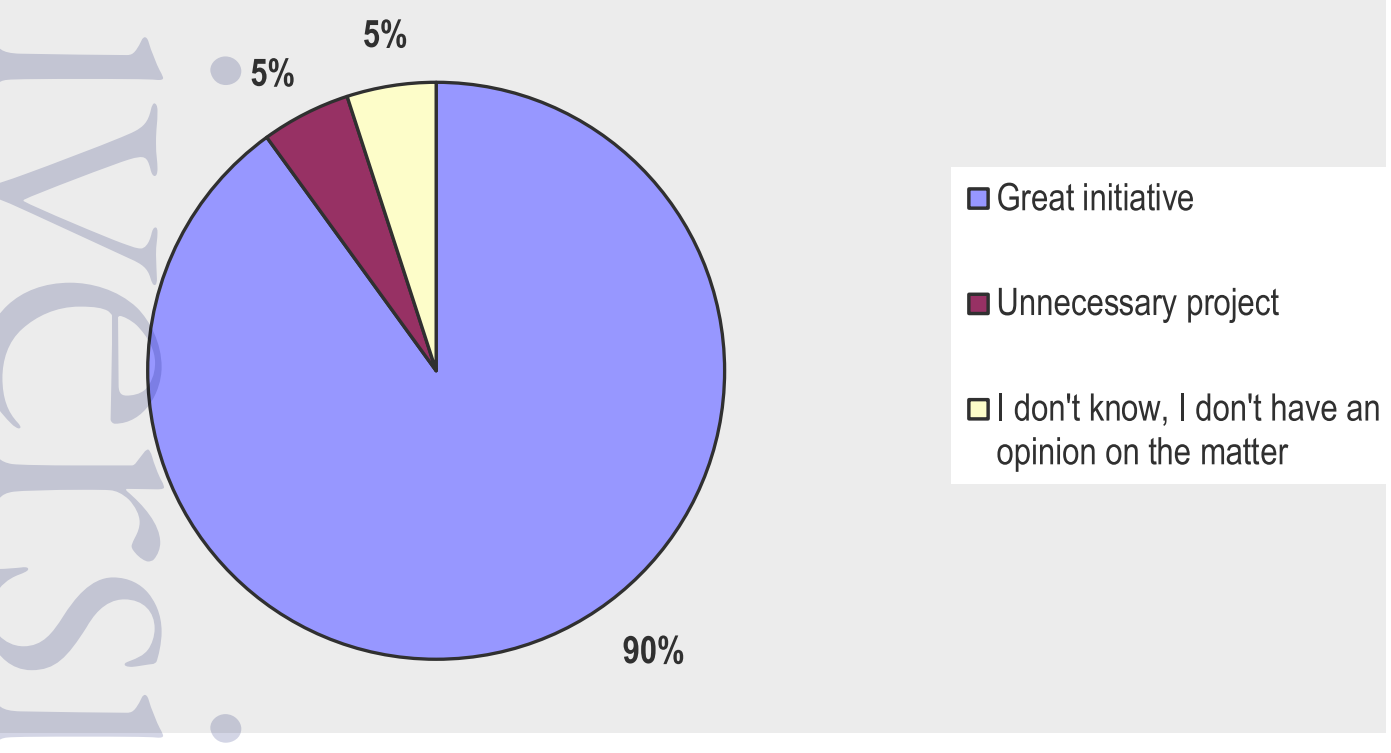

Chart 8: Citizens' opinion about the creation of an underwater museum in Zambratija Cove (Source: "Pinna nobilis" FLAG through SurveyMonkey online survey platform, www.surveymonkey.com)

cused on sustainability. All this will ultimately contribute to an increase in knowledge and citizens' level of awareness about archaeological findings in Zambratija Cove, as well as an increase in personal involvement in the creation of content, leading to greater recognition of the site and the sustainable development of the community.

Furthermore, as many as $90.0 \%$ of respondents strongly support the idea of creating an underwater museum to present the cultural and natural wealth of the underwater area of Zambratija Cove, as shown in chart 8. As many as $80.2 \%$ of respondents support the establishment of a special management zone in Zambratija Cove for the purpose of developing a new product based on the evaluation of cultural heritage and the biological features of the cove's undersea habitat (Chart Io).

To sum up, Zambratija Cove represents a unique archaeological site due to the preserved remains of prehistoric houses, stilt houses, and a shipwreck. Such a locality should not remain closed to a limited circle of experts. It is neces- sary to present the findings to the public and to make it possible to present the content discovered and researched by the archaeological community with the help of local fishermen and divers. The results of the survey show that respondents are only partially informed about underwater archaeological heritage in Zambratija Cove.

They perceive the findings as abstract but important, although most of them still perceive it as something that is not of great importance to them, nor do they have a specific understanding of its significance (a fact that became especially apparent during workshops with fishermen as a part of the pilot project). This perception should be changed through active communication with fishermen, as well as with the general public, through their inclusion in the discovery, interpretation and presentation of findings. This will allow the community to understand their own cultural identity, as well as the possible material potential of Zambratija Cove (e.g. tourism economics, employment opportunities, etc.). 


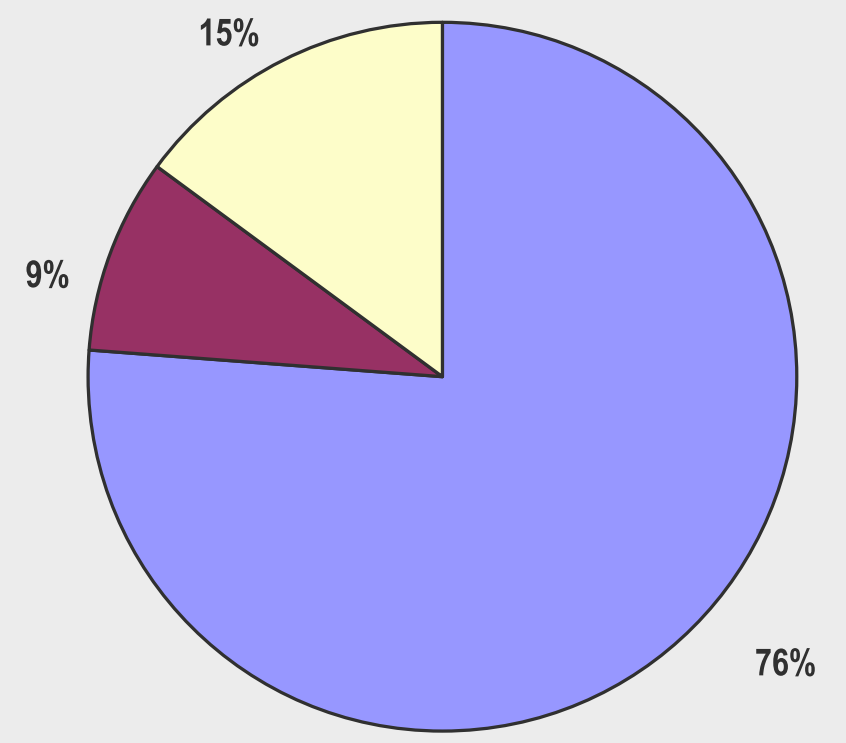

$\square$ Yes

$\square$ No

미 don't know

Chart 9: Respondents' attitude towards a reduction in fishing pressure in Zambratija Cove in order to create an underwater museum (Source: "Pinna nobilis" FLAG through SurveyMonkey online survey platform, www.surveymonkey. com)

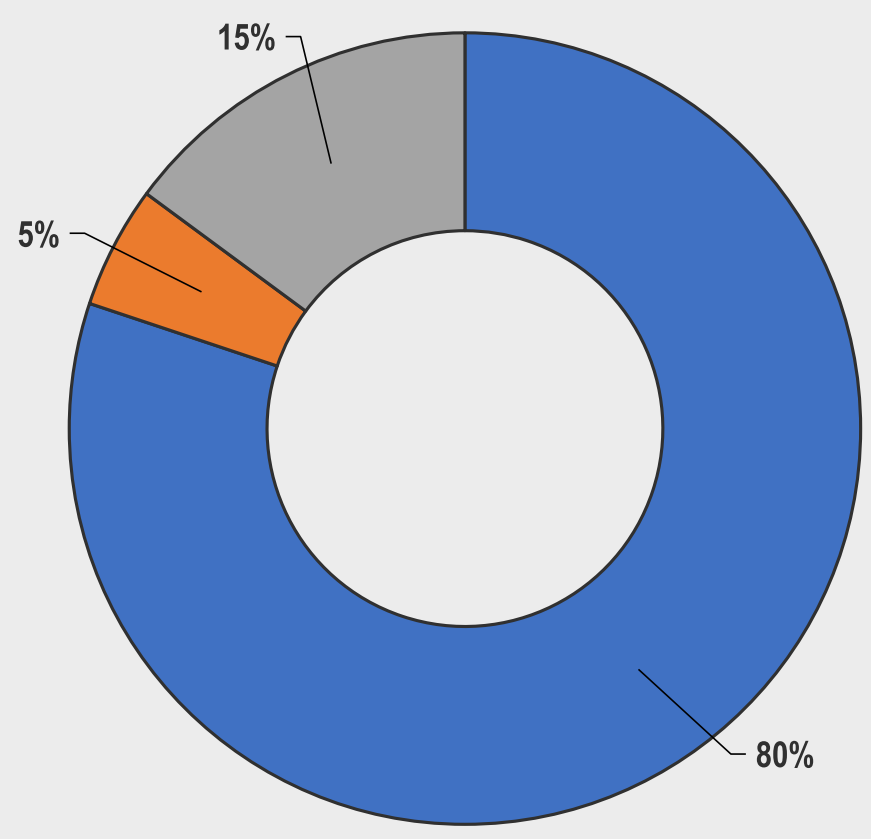

al support it

$\square$ ldon't support it

미 don't know
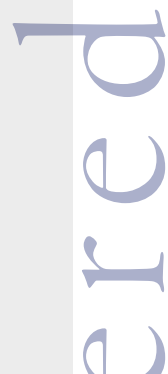
ing on the natural and cultural values of the cove could be built. It is extremely important to educate local people through targeted educational programs since they are mostly employed in tourism activities and engage in daily contact with visitors.

In order to prevent the further degradation of the habitat and the species Lithophaga lithophaga, the competent institutions must intensify the surveillance of the area and take all available measures to prevent destruction. It is especially important to emphasize that when the local population becomes aware of the cove area value, themselves will become its best guardians.

In conclusion, the implementation of the "Pinna nobilis" FLAG and "Batana salvorina" pilot project is intended to enable representatives of the fisheries sector and other interested citizens to actively participate in the process of considering possible development scenarios for the cove because of its archaeological and biological specificities. During the implementation of the pilot project, it was important to provide a stimulating environment in which to propose different ideas for the development of Zambratija Cove. It was also important to develop ideas that would interest the local fishermen. The guideline was the fact that the area of the archaeological site in Zambratija is shallow, up to $3 \mathrm{~m}$ deep, and is suitable for snorkelling. Fishermen who are interested in the development of fishing tourism would surely find economic benefit in this, and with the appropriate knowledge and skills, they would be able to diversify their sources of income. ${ }^{10}$

\section{Povzetek}

Območje okrog Zambratijskega zaliva je zaradi arheoloških zakladov edinstvena destinacija za raziskovalce. Leta 2008 so bile odkrite nove arheološke najdbe, ki veljajo za prvovrstna arheolopka odkritja. Lokalni prebivalci, člani društva za morske in kulturne znamenitosti »Savudrijska batana - Batana salvorina «, se zavedajo kulturnega, zgodovinskega in biološkega pomena

Io Iveša, Morskastaništa u uvali Zambratija; Koncani Uhač, Iveša, Žužić and Knežević, Zona posebnog upravljanja u uvali Zambratija. zaliva in vseh možnosti razvoja nove turistične, kulturne in izobraževalne ponudbe, zato so s podporo lokalne ribiške iniciative »Pinna nobilis « zagnali pilotni projekt »Posebno področje upravljanja v Zambratijskem zalivu (Umag) «.

Med trajanjem projekta je potekala študija podvodnih ekosistemov v Zambratijskem zalivu, oblikovane pa so bile tudi smernice za trajnostno rabo lokalnih naravnih virov. Turistična valorizacija je za lokalne prebivalce še vedno izziv, od toda pa tudi izvira potreba po spodbujanju lokalnih prebivalcev $\mathrm{k}$ aktivnemu sodelovanju pri oblikovanju scenarijev razvoja zaliva, ki je v arheološkem in biotskem pomenu posebnost.

\section{Summary}

The area surrounding Zambratija Cove has been representing a unique destination for researchers due to its archaeological treasures. In 2008 new archaeological findings were discovered, which, as a result of its uniqueness, can be classified at the very top of archaeological discoveries.

The local population, members of the "Savudrijska batana - Batana salvorina” Sea and Cultural Attractions Association, have recognized the cultural, historical and biological importance of the cove and the possibility of developing a new tourist, cultural and educational offer. With the technical support from "Pinna nobilis" Fisheries Local Action Group (FLAG), the pilot project entitled "Special Management zone in Zambratija Cove (Umag)" was developed.

Within the pilot project, a study of underwater communities in the Zambratija Cove was conducted, along with some guidelines for the sustainable use of natural resources in the area. Tourist valorisation is still a challenge for the inhabitants of the Zambratija area, therefore the need to encourage citizens to actively participate in the process of considering possible development scenarios of the cove because of its archaeological and biological specificities.

\section{Bibliography}

Boetto, Giulia, Ida Koncani Uhač and Marko Uhač. "Sewn Ships from Istria (Croatia): the Shipwrecks of Zambratija and Pula." In Baltic and Beyond, Change and Continuity in shipbuilding: Proceedings of 
the I4th International Symposium on Boat and Ship Archaeology, eds. Jerzy Litwin and Waldemar Ossowski, I89-98. Gdansk: National Maritime Museum, 2017.

Ferreira Dominguez, Alba, Giulia Boetto, Frédéric Guibal and Carine CenzonSalvayre. "Wood analysis." In Zambratija - Prehistoric sewn boat, eds. Ida Koncani Uhač, Giulia Boetto and Marko Uhač, 60-64. Pula: Arheološki muzej Istre, 2017.

Iveša, Neven. Morska staništa u uvali

Zambratija, Umag / Underwater communities in the Zambratija Cove. (July 20I7). http://www.lag-sjevernaistra. hr/wp-content/uploads/2017/07/ STUDIJA_Morska_stanista_u_uvali_ Zambratija_2017.pdf.

Koncani Uhač, Ida. "Podvodna arheološka istraživanja u uvali Zambratija / Underwater Archaeological Researches in Zambratija Cove." Histria Antiqua 17 (2009): 263-68.

Koncani Uhač, Ida. "Zambratija - uvala." Hrvatski arbeološki godišnjak s (2009): 396-98.

Koncani Uhač, Ida and Maja Čuka. “Doprinos poznavanju podmorskog eneolitičkog nalazišta u Zambratija / The underwater Eneolithic site at the Zambratija Cove: A Contribution to Knowledge." Histria Archeologica 46 (2016): 25-73.

Koncani Uhač, Ida and Marko Uhač. "Prapovijesni brod iz uvale Zambratija Prva kampanja istraživanja / Prehistoric Boat from Zambratija Cove - The First Campaign of Exploration." Histria Antiqua 2I (2012): 533-38.

Koncani Uhač, Ida and Marko Uhač. "La barca protostorica di Zambratija / Zambratia in Istria: risultati preliminari della prima campagna di scavo." Navis 5 (2014): 29-33.

Koncani Uhač, Ida, Giulia Boetto and Marko Uhač. Zambratija. Prapovijesni sivani brod / Prehistoric sewn boat / Una barca cucita preistorica / Un bateau cousu prébistorique. Pula: Arheološki muzej Istre, 2017.
Koncani Uhač, Ida, Marko Uhač and Giulia Boetto. "Il relitto di Zambratija, Istria, Croazia (XII-X sec. a. J.-C.).” In Atti del 2. convegno nazionale "Cultura navale e marittima - transire mare," eds. Maria Carola Morozzo della Roca and Francesco Tiboni, 214-19. Genova: GoWare, 2017. Koncani Uhač, Ida, Neven Iveša, Ana Žužić and Isabela Knežević. 2017. Zona posebnog upravljanja u uvali Zambratija (Umag) I Special management zone in Zambratija Cove (Umag). Novigrad: Lokalna akcijska grupa u ribarstvu "Pinna nobilis," 2017. 